УДК 51.755(479)

\author{
С. В. Діденко
}

\title{
ПОНЯТТЯ ТА ЕЛЕМЕНТИ МЕХАНІЗМУ АДМІНІСТРАТИВНО-ПРАВОВОГО ЗАБЕЗПЕЧЕННЯ ОБІГУ ТА ЗАСТОСУВАННЯ ЗБРОЇ В УКРАЇНI
}

Постановка проблеми. Основоположне завдання держави як цілісного утворення, покликання якого - захист інтересів своїх громадян, - це чітке, грамотне та своєчасне впорядкування певних суспільних відносин. Незаконний обіг зброї та іiі застосування як цивільним населенням, так і посадовцями вже стали буденним явищем.

Ось, зокрема, нещодавно відбулась стрілянина біля розформованої роти МВД «Торнадо» між бійцями спецроти і представниками військової прокуратури [1]; на території відомого мукачівського ринку «Гід» сталася сутичка 3 використанням травматичної зброї [2]; за допомогою зброї охоронець запобіг крадіжці на території залізниці [3]. У зв'язку з тим, що в Україні щороку реєструються тисячі злочинів, пов'язаних із незаконним обігом вогнепальної зброї, в умовах сьогодення все активніше набирає обертів у своїй актуальності питання забезпечення публічною адміністрацією всіма можливими засобами і способами максимального упорядкування усіх можливих відносин у цій сфері.

Аналіз останніх досліджень і публікацій. Багато науковців уже звертали свою увагу на цю проблему, серед них як вітчизняні, так і зарубіжні вчені-юристи, зокрема О.М. Бокій, А.Д. Благов, В.А. Гуменюк, А.А. Долгополов, Д.А. Корецький, А.В. Корнієць, А.В. Кофанов, І.А. Кузнєцова, О.М. Піджаренко, М.П. Федоров, Е.Д. Шелковникова та інші. Проте аналізованої нами проблематики вони торкалися лише опосередковано, досліджуючи інші, більш загальні, спеціальні та суміжні чинники. А отже, поняття та елементи механізму забезпечення обігу та застосування зброї в Україні в адміністративному аспекті досліджені поверхнево, безсистемно та потребують подальших наукових розробок.

Мета статті - на основі теорії адміністративного права, аналізу відповідних нормативно-правових актів, праць вчених та інших джерел з'ясувати поняття та елементи механізму забезпечення обігу та застосування зброї в Україні. 
Виклад основного матеріалу. Як зазначає С.С. Алексєєв, право виникає, тому що відповідно до вимог економічного базису на певній стадії розвитку суспільства необхідно за допомогою юридичних засобів упорядкувати суспільні відносини, увести їх у певні межі, забезпечити іх подальший розвиток, тобто відповідним чином юридично впливати на них $[4$, с. 12].

Виходячи з визначення, що адміністративно-правове забезпечення обігу та застосування зброї полягає у виявленні та створенні адміністративних засад та інструментарію реалізації адміністративно-правових відносин у цій сфері, а також охороні та гарантуванні прав, свобод і законних інтересів суб'єктів цих відносин на основі правових норм, на нашу думку, механізм адміністративно-правового забезпечення обігу та застосування зброї потрібно розглядати через призму механізму правового регулювання та брати його за основу під час формулювання відповідних висновків.

Така категорія, як «механізм», на думку професора О.М. Литвинова, відіграє в житті людини досить значну роль, оскільки вона застосовується практично в усіх сферах життєдіяльності суспільства, але особливо - у сфері суспільних відносин, де, як правило, пов'язується зі здійсненням певного явища, процесу, реалізацією відносин [5, с. 102].

3 цього випливає, що механізм адміністративно-правового забезпечення розповсюджується на певну сферу суспільних відносин, а його основним завданням є упорядкування суспільних відносин, щоб надалі мати змогу впливати на них.

На думку професора С.Г. Стеценко, сьогодні механізм адміністративно-правового регулювання суспільних відносин розуміється як категорія, що виражає процес переведення нормативності права в упорядкованість суспільних відносин, які нормами цієї галузі права регулюються. Іншими словами, правові норми, які використовуються в адміністративному праві, самі по собі статичні, а в рух вони приводяться саме за допомогою механізму адміністративно-правового регулювання [6, с. 212]. Механізм правового регулювання має свої особливості, які дають підстави виокремити його в самостійний вид впливу через правовідносини на поведінку адресатів - учасників суспільних відносин, наділених взаємними правами, обов'язками, відповідальністю, інакше - заборонами, дозволами [7, с. 11].

Виходить, що механізм адміністративно-правового забезпечення - це певний процес, тобто певний рух задля досягнення певної цілі, а його особливостями є коло учасників, на яких розповсюджується його вплив, i спосіб їх поведінки.

Специфічний механізм, на думку С.I. Хом'яченко, можна визначити як узята в єдності система правових засобів, за допомогою яких забезпечується результативний правовий вплив на суспільні відносини, і це поняття дає змогу не тільки зібрати разом явища правової дійсності (норми, правовідносини, юридичні акти тощо), окреслити їх цілісність, а й подати їх у вигляді, що працює та системно впливає. Так, Д. Коссе під механізмом правового регулювання пропонує розуміти системну сукупність правових заходів, за 
допомогою яких держава здійснює правовий вплив на суспільні відносини в необхідному для неї (держави) і суспільства напрямку [7, с. 11].

Таким чином, механізм правового забезпечення обігу та застосування зброї - це процес упорядкування суспільних відносин, що складаються в цій сфері суспільного життя, і являє собою систему певних правових засобів, за допомогою яких держава визначає поведінку суб'єктів цих відносин, тим самим виконуючи регулятивну та охоронну функції задля гарантування їхніх прав, свобод і законних інтересів.

Класик теоретичних засад механізму правового регулювання С.С. Алексєєв зазначає, що як динамічна категорія процес правового регулювання складається $з$ трьох основних стадій: перша - регламентація суспільних відносин, яка потребує правового опосередкування; друга - дія юридичних норм, у результаті яких виникають або змінюються правовідносини; третя - реалізація суб'єктивних юридичних прав та обов'язків [4, с. 16].

Це означає, що за аналогією спочатку механізм правового забезпечення встановлює поведінку певних учасників відносин у сфері обігу та застосування зброї, прописуючи їх у правових нормах, а потім починається їх дія та безпосередня реалізація.

Професори М.С. Кельман та О.Г. Мурашин зазначають, що мета механізму правового регулювання - забезпечити безперешкодний рух інтересів суб'єктів до цінностей, тобто гарантувати їх справедливе задоволення. Ця головна, змістовна ознака пояснює значущість цієї категорії та показує, що роль механізму правового регулювання полягає в усуненні можливих перепон, які стоять на шляху здійснення інтересів суб'єктів. Механізм правового регулювання - специфічний юридичний «канал», який з'єднує інтереси суб'єктів з цінностями і доводить процес управління до логічного результату [8, с. 207].

Саме тому метою механізму правового забезпечення обігу та застосування зброї є встановлення державою певних правових засад, які забезпечують законні права та інтереси суб’єктів цих відносин і виступають гарантом публічних суспільних інтересів у цій сфері.

У свою чергу, професор Т.С. Гончарук вважає, що механізм адміністративно-правового регулювання - це система адміністративно-правових засобів (елементів), за допомогою яких здійснюється правове регулювання (упорядкування) суспільних відносин у сфері державного управління [9, с. 742]. Тобто визначальне значення мають його елементи.

Отже, узагальнюючи наукові позиції, зазначимо, що механізм адміністративно-правового регулювання $€$ однією з провідних категорій адміністративного права, за допомогою якої здійснюється ефективний вплив на поведінку суб'єктів права.

Переходячи до розгляду його елементів, потрібно звернутись до наукових позицій з приводу трактування такого явища. Згідно із загальною теорією права до елементів механізму правового регулювання належать: юридичні норми; нормативно-правові акти; акти офіційного тлумачення; юридичні факти; правовідносини; акти правореалізації; правосвідомість 
і режим законності та правопорядку, який впроваджується в результаті досягнення цілей правового регулювання. Кожній стадії правового регулювання відповідають специфічні елементи механізму правового регулювання, місце яких у механізмі правового регулювання зумовлене їх функціональною роллю. Функціонування механізму правового регулювання відрізняється послідовністю: кожен з його елементів вступає в дію на певній стадії правового регулювання [10, с. 101]. Тобто залежно від стадії адміністративно-правового забезпечення суспільних відносин будуть різнитись і елементи його здійснення.

Зокрема, до системи елементів механізму адміністративно-правового регулювання (стадій правозастосування та правоохоронної діяльності) В.В. Галунько, В.І. Курило, С.О. Короєд відносять норми адміністративного права та їх зовнішнє вираження - джерела адміністративного права, принципи адміністративного права, тлумачення норм адміністративного права, адміністративно-правові відносини, адміністративно-правовий статус суб'єктів публічної адміністрації, індивідуальні адміністративні акти суб'єктів публічної адміністрації, форми адміністративної діяльності суб'єктів публічної адміністрації та методи, адміністративно-правові режими, адміністративні процедури, ефективність адміністративно-правового регулювання [11, с. 106].

Професор А.М. Вітченко до елементів механізму правового регулювання відносить норми права різного призначення, акти застосування права i діяльність організацій та посадових осіб по втіленню ї у життя. На його думку представлену структуру механізму можна вважати класичною, оскільки означені елементи в сукупності утворюють довершену систему правового забезпечення [12, с. 509].

Структуру механізму адміністративно-правового регулювання, на думку Т.С. Гончарука, складають адміністративно-правові норми, акти тлумачення та акти реалізації адміністративно-правових норм, адміністративно-правові відносини [9, с. 742].

У свою чергу професор 3.С. Гладун, розглядаючи механізм адміністративно-правового регулювання, виділяє в ньому елементи механізму та функціональні складові частини механізму. До елементів належать норми права - загальнообов'язкові правила поведінки, установлені з метою регулювання суспільних відносин; акти реалізації норм права - процес фактичного втілення в життя приписів правових норм через поведінку суб'єктів адміністративного права; правові відносини - вольові суспільні відносини, що виникають на основі норм права. До функціональних складових частин механізму адміністративно-правового регулювання належать юридичні факти; правова свідомість і правова культура; законність; акти тлумачення норм права; акти застосування норм права [13, с. 117].

Таким чином, узагальнюючи, можна стверджувати, що існує дві точки зору вчених щодо визначення складових частин механізму адміністративно-правового регулювання: одні перераховують всі можливі елементи, інші виокремлюють тільки ті, які, на їх думку, головні. 
Що ж стосується елементів адміністративно-правового забезпечення, то слід погодитись з думкою А.М. Вітченка, при цьому до елементів механізму забезпечення обігу та застосування зброї слід віднести:

1) норми права різного призначення, такі як закон України «Про Національну поліцію», «Інструкція про порядок виготовлення, придбання, зберігання, обліку, перевезення та використання вогнепальної, пневматичної і холодної зброї, пристроїв вітчизняного виробництва для відстрілу патронів, споряджених гумовими чи аналогічними за своїми властивостями метальними снарядами несмертельної дії, та зазначених патронів, а також боєприпасів до зброї та вибухових матеріалів» тощо;

2) акти застосування права і діяльність організацій та посадових осіб зі втілення їх у життя (форми та методи), як, наприклад, видання конкретній особі дозволу на володіння, зберігання, носіння зброї;

3) принципи адміністративного права, серед яких у сфері обігу та застосування зброї можна виділити принцип пріоритету прав і свобод людини та громадянина; принцип верховенства права та правового закону; принцип рівності однорідних суб'єктів адміністративного права перед законом; принцип демократизму; принцип взаємної відповідальності суб'єктів публічної адміністрації та об’єктів публічного управління, тощо;

4) тлумачення адміністративних приписів у цій сфері як процес доведення та уточнення їх змісту;

5) адміністративно-правові відносини, які базуються на адміністративно-правових нормах та виникають і здійснюються на їх основі;

6) адміністративно-правовий статус суб’єктів публічної адміністрації, що здійснюють адміністративно-правове забезпечення обігу та застосування зброї;

7) адміністративно-правові режими, зокрема обігу зброї на території України, ліцензування, тощо;

8) адміністративні процедури діяльності суб'єктів публічної адміністрації у сфері забезпечення обігу та застосування зброї.

Висновки. Усе викладене дає можливість сформулювати такі висновки щодо визначення характерних особливостей, притаманних механізму адміністративно-правового забезпечення обігу та застосування зброї в Україні:

- механізм адміністративно-правового забезпечення обігу та застосування зброї потрібно розглядати через призму механізму правового регулювання та брати його за основу, оскільки він $є$ однією з провідних категорій адміністративного права, за допомогою якої здійснюється ефективний вплив на поведінку суб'єктів права та має суміжні до виконання завдання наряду із категорією правового забезпечення;

- він розповсюджується на всі суспільні відносини, що виникають в сфері обігу та застосування зброї, а його основне завдання - упорядкування усіх можливих суспільних відносин в цій сфері, щоб надалі мати змогу впливати на них публічною адміністрацією;

- це певний процес, тобто спрямований рух, задля досягнення визначеної цілі, а його особливостями є коло учасників на яке розповсюджується його вплив та спосіб їх поведінки; 
- спочатку встановлює поведінку певних учасників відносин у сфері обігу та застосування зброї, прописуючи їх у правових нормах, потім починається їх дія та безпосередня реалізація;

- основною його метою є встановлення певних правових засад, які забезпечують законні права та інтереси суб'єктів цих відносин і виступають гарантом публічних суспільних інтересів у цій сфері;

- залежно від стадії адміністративно-правового забезпечення суспільних відносин будуть різнитись і елементи його здійснення, серед яких норми права різного призначення, акти застосування права і діяльність організацій та посадових осіб зі втілення їх у життя (форми та методи), а також принципи адміністративного права, тлумачення норм адміністративного права, адміністративно-правові відносини, адміністративно-правовий статус суб'єктів публічної адміністрації, адміністративно-правові режими, адміністративні процедури.

Отже, механізм правового забезпечення обігу та застосування зброї це і процес упорядкування усіх можливих суспільних відносин, що складаються в цій сфері суспільного життя, і система певних правових засобів, за допомогою яких держава визначає поведінку суб'єктів цих відносин, тим самим виконуючи регулятивну та охоронну функції задля гарантування їхніх прав, свобод і законних інтересів.

\section{Література}

1. У Боярці виникла стрілянина між бійцями "Торнадо" та працівниками військової прокуратури // 112.ua. - 2015. - [Електронний ресурс]. - Режим доступу : http://ua.112. ua / avarii-np / u-boiartsi-vynykla-strilianyna-mizh-biitsiamy-tornado-ta-pratsivnykamy-viiskovoiprokuratury-304840.html.

2. «Розборки» в Мукачеві: двоє поранені внаслідок стрілянини // uzhgorod. - 2015. [Електронний ресурс]. - Режим доступу : http:/ / uzhgorod.net.ua/news/94336.

3. На Закарпатті з боєм затримали молодого злодія / / tyachivnews. - 2015. - [Електронний pecypc]. - Режим доступу : http://tyachivnews.in.ua/novini/zakarpattya/7742-na-zakarpatt-zboyem-zatrimali-molodogo-zlodya.html.

4. Алексеев С.С. Механизм правового регулирования в социалистическом государстве / С.С. Алексеев. - М. : Юрид. лит., 1966. - 187 с.

5. Литвинов О.М. Соціально-правовий механізм протидії злочинності в Україні : [монографія] / О.М. Литвинов ; Харківський національний ун-т внутрішніх справ. - Х., 2008. - 446 с.

6. Стеценко С.Г. Адміністративне право України : [навч. посіб.] / С.Г. Стеценко. - К. : Атіка, 2007. - 624 c.

7. Хом'яченко С.І. Особливості механізму адміністративно-правового регулювання цивільної авіації / С.I. Хом'яченко. / / Юридичний вісник. - 2014. - № 2 (31) - С. 11-13.

8. Кельман М.С. Загальна теорія права : [підруч. для студ. вищ. навч. закл.] / М.С. Кельман, О.Г. Мурашин ; Нац. акад. внутр. справ України. - К. : Кондор, 2002. - 353 с.

9. Плугатар Т.А. Сутність механізму адміністративно-правового регулювання діяльності міліції України / Т.А. Плугатар / / Форум права. - 2011. - № 2. - С. 741-744.

10. Волинка К.Г. Теорія держави і права : [навч. посіб.] / К.Г. Волинка. - К. : МАУП, 2003. $-240 \mathrm{c}$

11. Галунько В.В. Адміністративне право України. Т. 1. Загальне адміністративне право : [навч. посіб.] / [В.В. Галунько, В.І. Курило, С.О. Короєд, О.Ю. Дрозд та ін.]; за ред. проф. В.В. Галунька. - Херсон : Грінь Д.С., 2015. - 272 с.

12. Слабунова Ю.В. Структура адміністративно-правового механізму забезпечення прав громадян органами прокуратури / Ю.В. Слабунова // Форум права. - 2013. - № 2. - С. 508-512. 
13. Корсун C.I. Механізм адміністративно-правового регулювання запобігання фінансуванню тероризму / С.I. Корсун // Науковий вісник Міжнародного гуманітарного університету. Серія: Юриспруденція : зб. наук. пр. / Міжнар. гуманіт. ун-т. - О. : МГУ, 2010. - С. 116-118.

\section{А нот а ц і я}

Діденко C. В. Поняття та елементи механізму адміністративно-правового забезпечення обігу та застосування зброї в Україні. - Стаття.

У статті доведено, що механізм адміністративно-правового забезпечення обігу та застосування зброї - це процес упорядкування суспільних відносин, що складаються у сфері обігу та застосування зброї, стосовно системи правових засобів, які забезпечують законні права та інтереси суб'єктів таких відносин. Ці засоби є гарантом публічних суспільних інтересів, і завдяки їм визначається поведінка суб'єктів адміністративного права, що здійснюється за допомогою норм адміністративного права, актів застосування права й адміністративної діяльності суб'єктів публічної адміністрації зі втілення їх у життя (форми та методи), а також принципів адміністративного права, тлумачення норм адміністративного права, адміністративно-правового статусу, адміністративно-правових режимів та адміністративних процедур.

Ключові слова: елементи механізму забезпечення, застосування зброї, зброя, механізм адміністративно-правового забезпечення, обіг зброї.

\section{Анн о т а ци я}

Диденко C. B. Понятие и элементы механизма административно-правового обеспечения оборота и применения оружия в Украине. - Статья.

В статье доказано, что механизм административно-правового обеспечения оборота и применения оружия - это процесс упорядочения общественных отношений, складывающихся в сфере оборота и применения оружия в отношении системы правовых средств, обеспечивающих законные права и интересы субъектов таких отношений. Эти средства выступают гарантом публичных общественных интересов, и благодаря ним определяется поведение субъектов административного права, которое осуществляется с помощью норм административного права, актов применения права и административной деятельности субъектов публичной администрации по воплощению их в жизнь (формы и методы), а также принципов административного права, толкования норм административного права, административно-правового статуса, административно-правовых режимов и административных процедур.

Ключевые слова: механизм административно-правового обеспечения, оборот оружия, оружие, применения оружия, элементы механизма обеспечения.

\section{S u m m a r y}

Didenko S. V. Concept and elements of mechanism of administrative and legal support circulation and use of weapons in Ukraine. - Article.

The article proved that the mechanism of administrative and legal support circulation and use of weapons - the process of ordering all possible social relations emerging in this field of public life. It is a system of specific legal measures that ensure the legitimate rights and interests of subjects these relationships and is acting as guarantor of public interests. The process of ordering is carried out by identified elements.

Key words: circulation of weapons, mechanism of administrative and legal support, elements of provide mechanism, use of weapons, weapons. 